膵管空腸側々吻合術を施行した慢性背側膵炎の 1 例

\author{
名古屋大学第 1 外科 \\ 土江 健嗣 二村 雄次 早川 直和 神谷 順一 \\ 長谷川 洋岡本勝司岸本 秀雄塩野谷恵彦

\section{A CASE OF CHRONIC DORSAL PANCREATITIS TREATED BY PANCREATICO-JEJUNOSTOMY}

\section{Kenji TSUCHIE, Yuji NIMURA, Naokazu HAYAKAWA, Junichi KAMIYA, Hiroshi HASEGAWA, Katsushi OKAMOTO, Hideo KISHIMOTO and Shigehiko SHIONOYA}

The First Department of Surgery, Nagoya University School of Medicine

索引用語：茦管非融合, 慢性背側膵炎, 腪管空腸側々吻合

はじめに

腹側膵管系と背側萊管系の非融合例には膵炎もしく は膵炎様発作を認める症例が多く，これには背側腪管 系の導管口である副乳頭開口部が大きく関与している と考劣られている.今回われわれは背側荤管系のびま ん性拡張と荤石を認めた荤管非融合例に苹管空腸側々 吻合術を施行し良好な結果を得た症例を経験したので 文献的考察を加学て報告する。

$$
\text { 症例 }
$$

年歯・性：48歳, 男性.

主訴：全身倦䓌感, 左脐部痛.

既往歴：特記すべきことなし。

家族歴：母親に糖尿病を認める。

飲酒歴：認めず.

現病歴：15年前より疲れやすい. 背部重王感があっ た. 昭和56年ごろより主訴が出現し近医で糖尿病を指 摘された。昭和 59 年 7 月, 倦总感消失せず某院内科受 診し, 荤石症, および膵管非融合を指摘された。昭和 59 年 9 月精查のため名大病院内科入院, 同年11月手術 目的のため名大第 1 外科に転科した。 入院時現症：頖 血, 黄疸を認めず㑪周囲に腹痛あるす压痛は認めな かった，血液生化学的所見では空腹時血糖の高值を認 め，検尿所見では尿糖井を認めたが，血中，尿中アミ ラーゼ值は，正常であった。な拈 $50 \mathrm{~g}$ oral glucose

$<1986$ 年 4 月 9 日受理>別刷請求先：土江 健嗣 ₹466 名古屋市昭和区鶴舞町65 名古屋大学医学部 第 1 外科 tolerance test (50gOGTT) では糖尿病型を示し, pancreozymin-secretin test (PStest) では膵酵素量, 重炭酸塩濃度の 2 因子の低下を認めた。腹部超音波検 查および computed tomography (CT) 検査では主膵 管の拡張と腪石が認められたが(図 1), 主乳頭からの 内視鏡的逆行性荤胆管造影 endoscopic retrograde cholangio-pancreatography (ERCP) では, 胆管に拡 張, 㹟窄はなく, 拡張して短い、末梢では樹枝状となっ た䐙管が造影された(図 2 ). 副乳頭からの ERCP 検查 は成功しなかったが, 脞管非融合例 (pancreas divisum)で, 背側荤管の高度拡張と膵石を伴う慢性背

図 1 CT 像：主膵管の拡張と桠石を認める。

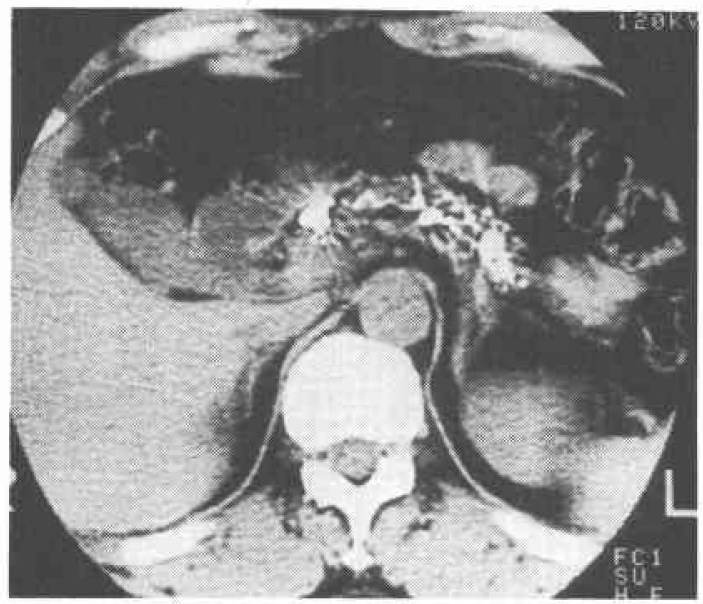


図 2 主乳頭からの ERCP 像（腹側胼管）：末梢が樹 枝状となった払張して短かい膵管が造影された。

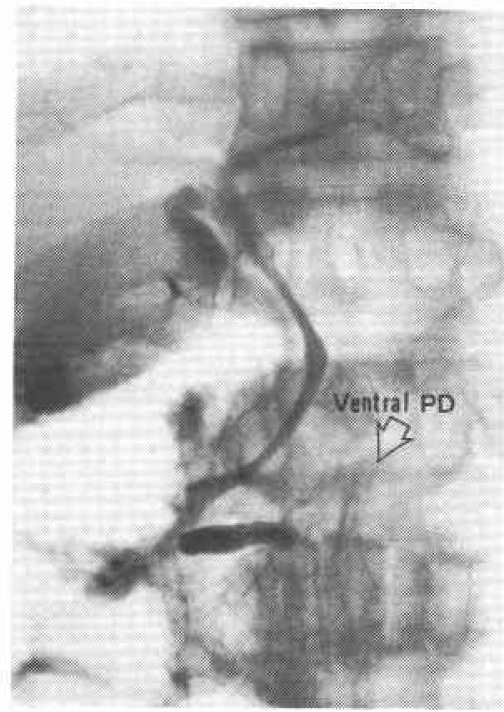

図 3 術中写真：膵は全体に萎縮し, 硬化が著しい。

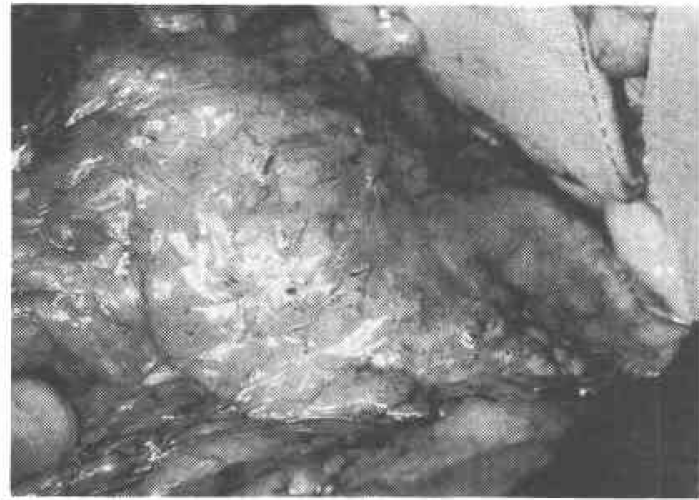

側膵炎と診断し，背側朠管のドレナージを目的として 昭和59年12月脞管空腸側々吻合術 (Partington's operation) $)^{1)}$ 施行した。

術中所見：膵は全体に硬く, 体部, 尾部は萎樎し, 分枝内の結石が透見でき，拡張した膵管を触知できた (図 3 ).

術中膵管造影では背側膵管は, 主膵管も分枝もびま ん性に拡張していた，造影剂は副乳頭のみを通って十 二指腸に流出し，腹側䏝管との交通は認められなかっ た（図 4 ）．背側膵管を約 $10 \mathrm{~cm}$ にわたり切開すると， 膵管の中に鋳型状に嵌頓した膵石が数個認められた。 膵管の拡張は約 $10 \mathrm{~mm}$ であった(図 5 )。摘出した脞石
図 4 術中背側莁管造影像：背側腪管およびその分枝 はびまん性に拡張し，造影剤は副乳頭（矢印）のみ を通って十二指腸に流出した，腹側膵管との交通は 認められない。

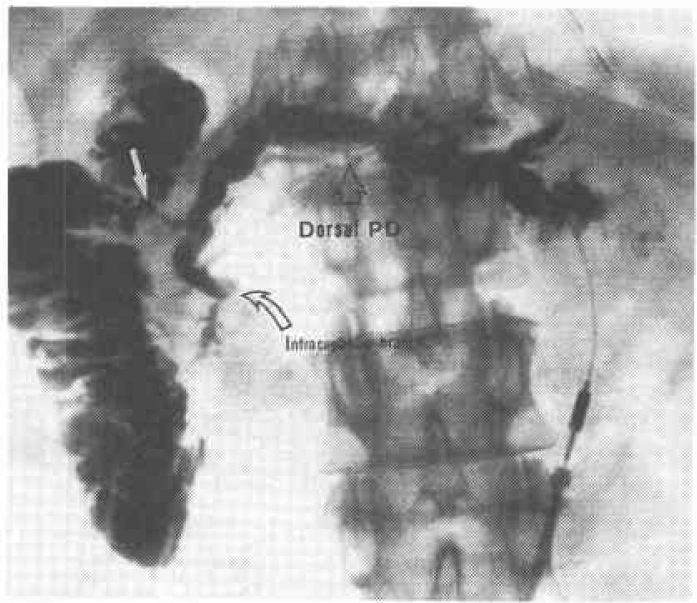

図 5 背側荤管を切開すると荤管内に鋳型状に嵌頓し


あった。

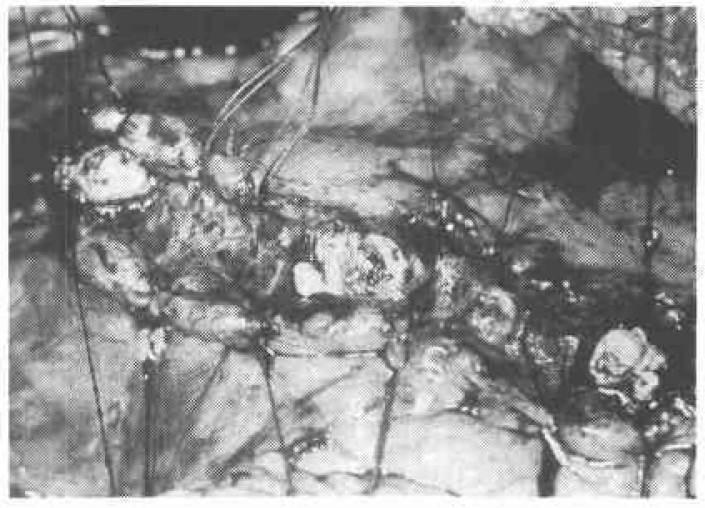

は黄白色から白色で $10 \mathrm{~mm}$ 大のが 3 個, $3 \mathrm{~mm}$ から 5 $\mathrm{mm}$ 大の 6 個，計 9 個であった(図6).な拉，この症 例では術前に胆囊のコレステロールポリープの存在も 指摘されており, 胆囊も同時に摘出した。

組織所見：荤管切開時に採取した膵実質は線維化が 強く外分泌腺の脱落がみられ㬸管分枝の増生と円形細 胞浸潤を認める慢性膵炎の所見であった(図 7)。患者 は術後 8 力月を経た現在腹痛もなく健在である。

\section{考察}

膵管非融合症例は欧米では，ERCP 施行例の3.0\% ～5.8\%に認められると報告されているが23)，本邦で 
図 6 摘出された背側膵管内の荤石. 色嗄白色から 白色で, $10 \mathrm{~mm}$ 大が 3 個, $3 \mathrm{~mm}$ から $5 \mathrm{~mm}$ 大が 6 個, 計 9 個であった。

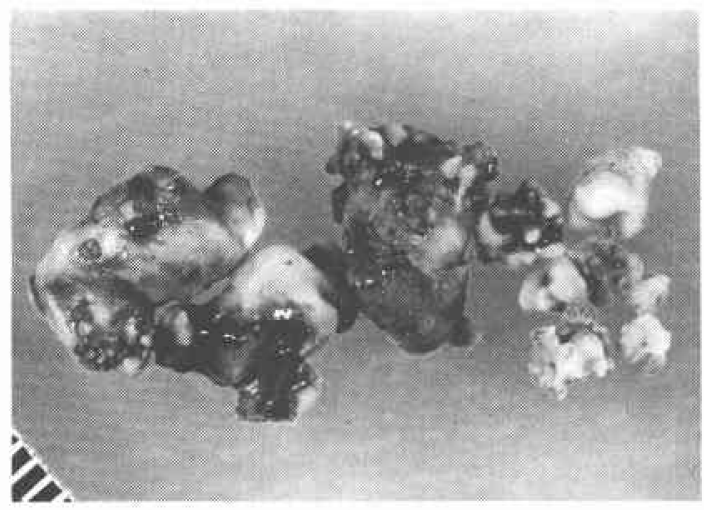

図 7 組織所見：線維化が著明で, 外分泌腺の脱落が 見られ，荤管分枝の増生と円形細胞浸潤を認める。 Hematoxylin-Eosin 染色 $\times 10$

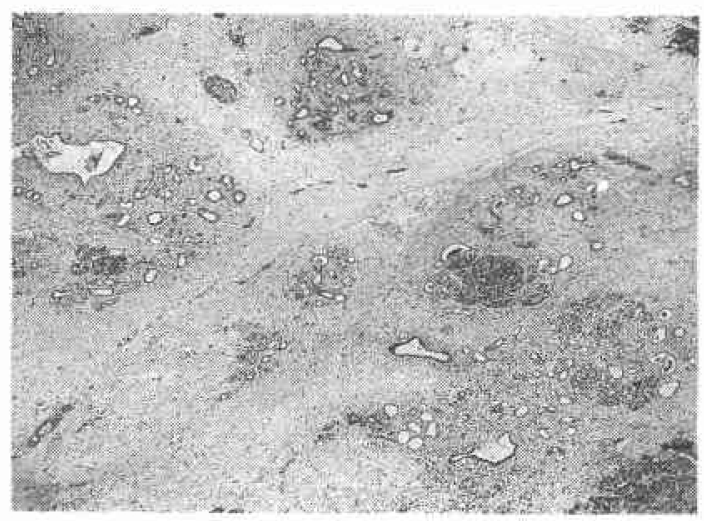

は $1 \%$ 前後の頻度で見られるという報告 ${ }^{45)}$ が多いそ の診断には副乳頭からの背側膵管の造影で腹側苹管と の交通がないことを証明することが不可欠である。わ れわれの症例は術前，頭乳頭からの造影はできなかっ たが, 術中の荤管造影で体管非融合の診断が可能で あった。膵管非融合症例に和いては膵炎様発作もしく は苹资を伴うすのが多ことが報告されており2336)7)，こ の原因として副乳頭口からの荤液の流出障害が想定さ れている22316)899). しかしながら,形態学的に苹管造影で 慢性脞炎所見を認める背側腪管像を見ることはめずら しく，自験例のようにびまん性の苾管拉張や荤石を認 めることはまれである.われわれの症例は飲酒歴もな く, 慢性荤炎の成因として荤液のらっ滞が強く推測さ れ, Dreiling らが10)が主張する obstruction-hyperse- cretion theoryを支持する典型的な症例と考えてい る.

膵管非融合に伴ら腪炎や腪炎様疼痛発作はその原因 が副乳頭口の狭窄が原因と推测されているため，これ らの症状を伴ら症例に対する外科的治療は, 副乳頭形 成術に主眼が括かれて拐り，欧米では良好な結果が報 告されている899)11) 14). Warshaw ら ${ }^{14)}$ は副乳頭形成術 の予後として副乳頭口の狭いものほど，また術前に疼 痛発作の著るしかったるの㴗ど効果的であったと報告 しているが, 自験例のように高度の荤管拡張を伴い線 維化が著しい慢性膵炎症例にたいしては膵管空腸吻合 および傘切除が必要であると述べている. Cottonら は3)内視鏡的副乳頭切開術を行い効果的であった症例 を報告しているが，これらの症例はいずれす短期間で 副乳頭口の再狭窄が起きたと述べている，本邦では腪 管非融合例で背側荤管に異常像を認めた報告15)16)や僈

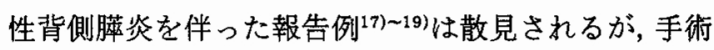
報告例は見られない.なお，本症例では腹側荤管の拡 張も認めた. Cotton らは背側膵管に高度の炎症性変化 を認めた荤管非融合例は腹側脞管にも異常を認めるこ

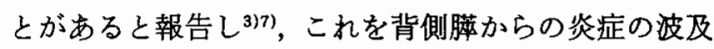
によるものと推測している，われわれの症例の腹側脺 管の变化も同様の様序が推測されるが, 腹側膵にのみ 炎症性変化を認める症例子存在する20)ことから断定は できない.

$$
\text { まとめ }
$$

腹側荤管系と背側膵管系の非融合例で膵石を伴う背 側膵管系のびまん性抬張を認めた慢性背側膵炎に対し て，荤管空腸側々吻合術を施行し，良好な結果を得た 1 症例を報告した。

本論文の要旨は第214回東海外科学会で報告した.

$$
\text { 文献 }
$$

1) Partington PF, Rochelle RE: Modified procedure for retrograde drainage of the pancreatic duct. Ann Surg 152: 1037-1043, 1960

2) Rosch W, Koch H, Schaffner $\mathrm{O}$ et al: The clinical significance of the pancreas divisum. Gastrointest Endosc 22 : 206-207, 1976

3) Cotton PB: Congenital anomaly of pancreas divisum as cause of obstructlve pain and pancreatitis. Gut $21: 105-114,1980$

4）中野 哲, 綿引 元, 武田 功ほか：ERCPで主脺 管の短小像を示した症例の検討一Shortmain pancreatic duct syndromeの提唱一. Gastroenterol Endosc $20: 828-835,1978$

5）小西孝司, 大田哲生, 泉 良平ほか：背側・腹側荤 
管非痖合例の臨床的検討，胆と满 $3: 1601-$ 1607, 1982

6) Gregg JA : Pancreas divisum : Its association with pancreatitis. Am J Surg $134: 539-543$, 1977

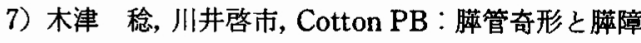
害一膵 malfusion の ERCP 所見を中心にして。臨 放線 23：1353-1358，1978

8) Cooperman M, Ferrara JJ, Fromkes JJ et al : Surgical management of pancreas divism. Am J Surg $143: 107-112,1982$

9) Richter JM, Schapiro RH, Mulley AG et al: Association of pancreas divisum and pancreatitis, and its treatment by sphincteroplasty of the accessory ampulla. Gastroenterology 81:1104-1110, 1981

10) Dreiling DA, Richman A, Fradkin NF et al: The role of alcohol in the etiology of pancreatitis. A study of the effect of intravenous ethyl alcohol on the external secretion of the pancreas : Gastroenterology $20: 636-646,1952$

11) Gregg JA, Monaco AP, McDermott WV : Pancreas divisum result of surgical intervention. Am J Surg $145:$ 488-492, 1982

12) Russell RCG, Wong NW, Cotton PB: Accessory sphincterotomy (endoscopic and surgical) in patients with pancreas divisum. Br J Surg
$71: 954-957,1984$

13) Keith RG, Shapero TF, Saibil FG: Treatment of pancreatitis associated with pancreas divisum by dorsal duct sphincterotomy alone. Can J Surg 25 : 622-626, 1982

14) Warshaw AL, Richter JM, Schapiro RH et al : The cause and treatment of pancreatitis associated with pancreatitis associated with pancreas divisum. Ann Surg $198:$ 443-452, 1983

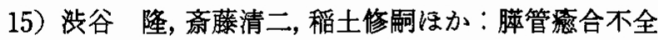
症に括ける䐙管像の検討. Gastroenterol Endosc $26: 1278-1284,1984$

16）矢崎康幸, 関谷千尋, 北川 隆注か：背・腹側朠非 瘾合例の内視鏡的経副乳頭滕管造影における先細 カニューレの有用性. Gastroenterol Endosc 24 : $467-472,1982$


合併した高度慢性背側苹炎の 1 例. Gastroenterol Endosc 24：1118-1124，1982

18）土岐文武，子井 至, 斎藤明子ほか：慢性背側满炎 の 1 例。日消病会誌 $77: 90-93 ， 1980$

19）李 文英, 土岐文武, 大井 至注か：荼管 malfusion 例飞合併した慢性䐙炎の 1 例. 胆と脇 2 ： 1057-1062, 1981

20）太田哲生，小西孝司，宮琦逸夫ほか：背側・腹側䐙 管非癒合例飞合併した慢性腹側膵炎の 1 例。胆と 腪 $3: 1351-1356,1982$ 